$\mathrm{T}$ -клеточные лимфомы кожи: дифференциальная диагностика эритродермических состояний

Карамова А. Э., Чикин В. В., Знаменская Л. Ф., Воронцова А. А. *

Государственный научный центр дерматовенерологии и косметологии

Министерства здравоохранения Российской Федерации

107076, Российская Федерация, г. Москва, ул. Короленко, д. 3, стр. 6

Эритродермия - поражение не менее 80-90 \% поверхности кожи, характеризующееся эритемой и шелушением, которые могут быть проявлением различных заболеваний кожи и внутренних органов, в том числе злокачественного лимфопролиферативного процесса. Синдром Сезари (СС) и эритродермическая фрорма грибовидного микоза (Э-ГМ) относятся к агрессивным вариантам течения Т-клеточной лимфомы кожи, диагностика которых сопряжена со многими сложностями ввиду схожести клинической картины этих заболеваний с доброкачественными дерматозами. В статье представлены два клинических случая эритродермии при Т-клеточной лимфоме кожи. В результате анализа анамнестических данных, клинической картины и результатов лабораторного обследования у больных установлен диагноз синдрома Сезари. Представленные случаи подчеркивают важность выявления причин эритродермии.

Ключевые слова: эритродермия, Т-клеточная лимфома кожи, грибовидный микоз, синдром Сезари, эритродермическая форма грибовидного микоза

Конфрликт интересов: авторы заявляют об отсутствии потенциального конфлликта интересов, требующего раскрытия в данной статье.

Для цитирования: Карамова А. Э., Чикин В. В., Знаменская Л. Ф., Воронцова А. А. Т-клеточные лимфомы кожи: дифрференциальная диагностика эритродермических состояний. Вестник дерматологии и венерологии. 2019;95(5):24-32. https://doi.org/10.25208/0042-4609-2019-95-5-24-32 


\section{Cutaneous T-cell lymphoma: Differential diagnostics of erythrodermic conditions}

Arfenya E. Karamova, Vadim V. Chikin, Lyudmila F. Znamenskaya, Anastasia A. Vorontsova*

State Research Center of Dermatovenereology and Cosmetology, Ministry of Health of the Russian Federation Korolenko str., 3, bldg 6, Moscow, 107076, Russian Federation

Erythroderma is a condition damaging at least $80-90 \%$ of the skin surface, characterized by erythema and peeling. This condition may be a manifestation of various diseases of the skin and internal organs, including malignant lymphoproliferative disorders. Sézary syndrome and the erythrodermic variant of mycosis fungoides are aggressive forms of cutaneous T-cell skin lymphoma, the diagnostics of which is challenging due to the similar clinical pictures of these diseases with benign dermatoses. This article presents two clinical cases of erythroderma in the setting of cutaneous T-cell lymphoma. An analysis of the anamnestic data, the clinical picture and the results of laboratory examinations in patients suffering from this condition allowed the diagnosis of Sézary syndrome to be confirmed. The presented cases reflect the importance of identifying the causes of erythroderma.

Keywords: erythroderma, cutaneous T-cell lymphoma, mycosis fungoides, Sézary syndrome, erythrodermic variant of mycosis fungoides

Conflict of interest: the authors state that there is no potential conflict of interest requiring disclosure in this article.

For citation: Karamova A. E., Chikin V. V., Znamenskaya L. F., Vorontsova A. A. Cutaneous T-cell lymphoma: Differential diagnostics of erythrodermic conditions. Vestnik Dermatologii i Venerologii. 2019;95(5):24-32. https://doi.org/10.25208/0042-4609-2019-95-5-24-32 
Эритродермия (синоним: эксфролиативный дерматит) - поражение кожи в виде эритемы и шелушения, занимающее 90 \% и более поверхности кожного покрова [1-3]. У взрослых эритродермия чаще отмечается в возрасте от 41 до 61 года, в среднем - в 55 лет [4]. У мужчин это патологическое состояние встречается в 2-4 раза чаще, чем у женщин [4]. У детей эритродермия развивается в среднем в возрасте 3,3 года, соотношение мальчиков и девочек составляет 0,89: 1 [5].

Наиболее частой причиной развития эритродермии у взрослых является псориаз, к другим причинам относят атопический дерматит, лекарственную токсидермию, питириаз красный волосяной отрубевидный (болезнь Девержи), листовидную пузырчатку, реже - экзему [6-8].

Среди первичных Т-клеточных лимфом кожи (ТКЛК) эритродермическое состояние встречается при синдроме Сезари (СС) и эритродермической форме грибовидного микоза (Э-ГМ) [6, 9, 10]. Клинические проявления при Э-ГМ и СС схожи и помимо эритродермии могут включать в себя гиперкератоз ладоней и подошв, диффузное выпадение волос и/или алопецию. Кроме кожных проявлений у больных может наблюдаться лимфаденопатия и вовлечение в патологический процесс периферической крови, где обнаруживаются измененные Т-лимфоциты - клетки Сезари, несущие на себе аберрантный иммунофренотип [11, 12].

Оценка степени вовлечения периферической крови в патологический процесс является основным дифференциально-диагностическим критерием между Э-ГМ и СС. Согласно предложенной Международным обществом по изучению лимфом кожи (ISCL) и Европейской организацией по изучению и лечению рака (EORTC) системе стадирования ГМ и СС, отсутствие клеток Сезари В крови или обнаружение их $\leq 5 \%$ (В0), а также наличие в крови $>5 \%$, но $\leq 20 \%$ клеток Сезари (B1) принято считать низкой опухолевой нагрузкой, высокая опухолевая нагрузка определяется при обнаружении >1000 клеток/ мкл или >20 \% клеток Сезари (В2) $[13,14]$. При Э-ГМ уровень опухолевой нагрузки в крови не превышает В1, В то время как при СС степень вовлечения крови в патологический процесс оценивается как В2. Консорциумом ISCL_EORTC введены дополнительные критерии классификации, включающие оценку иммунофенотипа клеток; так, при СС наблюдается соотношение клеток, несущих на своей поверхности маркеры CD4 : CD8 $\geq 10$, а также потеря маркера CD7 на $40 \%$ или CD26 на $30 \%$, В то время как классический иммунофенотип при ГМ соответствует зрелым Т-клеткам памяти, экспрессирующим $\mathrm{CD}^{+}, \mathrm{CD}^{+}, \mathrm{CD}^{+}, \mathrm{CD}^{+}, \mathrm{CD}^{2} \mathrm{RO}^{+}$, экспрессия же CD8 в большинстве случаев отсутствует [15-17].

Диагностика эритродермических состояний при лимфопролиферативных процессах сложна не только ввиду схожести клинико-патологических данных этих заболеваний с таковыми при доброкачественных дерматозах, но и между собой. В качестве иллюстрации непростого алгоритма диффреренциальной диагностики этих двух состояний приводим клинические случаи.

\section{Клинический случай 1}

Пациент Ф., 50 лет, поступил в отделение ФГБУ «ГНЦДК» Минздрава России с жалобами на распространенные высыпания на коже волосистой части головы, лица, туловища, верхних и нижних конечностей, сопровождавшихся выраженным зудом.
Пациент болен с 2010 года, когда в возрасте 45 лет появился умеренный зуд кожи туловища, верхних и нижних конечностей. При обращении к дерматологу в КВД по месту жительства диагноз установлен не был, лечение не проводилось. Умеренный зуд сохранялся. В 2014 году пациент отметил появление высыпаний ярко-розового цвета, сопровождавшихся шелушением и интенсивным зудом, в связи с чем находился на стационарном лечении в МНПЦДК филлиал им. В. Г. Короленко с диагнозом: «Псориатическая эритродермия», где проводилась терапия дипроспаном 2 мл в/м № 1, а также дезинтоксикационными и десенсибилизирующими средствами с кратковременным положительным эфрфектом. При ухудшении со стороны кожного патологического процесса пациент самостоятельно проводил внутримышечные инъекции дипроспана по 1 мл 1 раз в 1-2 месяца в течение полутора лет и наружно использовал топические глюкокортикостероидные средства. В марте 2016 года в связи с сохраняющимися высыпаниями и отсутствием эффекта от проводимой терапии пациент обратился в КДЦ ФГБУ «ГНЦДК» Минздрава России, где рекомендовалось лечение в условиях стационара.

При поступлении кожный патологический процесс носил характер эритродермии. Кожные покровы имели ярко-розовую окраску с множественными чешуйко-корками и множественными экскориациями. На коже волосистой части головы наблюдалось обильное мелкопластинчатое шелушение, участки поредения волос. На коже спины, волосистой части головы на фоне яркой эритемы имелись единичные эрозии ярко-розового цвета до 1,5 см в диаметре с влажной поверхностью. На коже боковых поверхностей туловища - участки «просветления», напоминающие «островки здоровой кожи». В области лучезапястных и голеностопных суставов имелись участки выраженной инфильтрации и лихенификации. На коже ладонных поверхностей кистей отмечался умеренный гиперкератоз, на коже подошвенных поверхностей стоп - выраженный гиперкератоз (рис. 1). У пациента выявлена лимфаденопатия: подчелюстные, подмышечные и паховые лимфоузлы были увеличены до 3 см в диаметре, плотноэластической консистенции, не спаяны с окружающими тканями, безболезненные при пальпации.

Учитывая клинико-анамнестические данные, проводилась дифференциальная диагностика между Т-клеточной лимфомой кожи, красным волосяным лишаем Девержи. Наличие гиперкератоза ладоней и подошв, лимфоаденопатии, а также появление кожного зуда задолго до первых высыпаний указывало на лимфопролиферативное заболевание кожи; с другой стороны, «островки здоровой кожи» на фроне эритродермии, гиперкератоз ладоней и подошв характерны для красного волосяного лишая Девержи. Наличие эрозий послужило основанием для проведения цитологического исследования мазка-отпечатка. Акантолитические клетки обнаружены не были.

При морфологическом исследовании биоптата кожи с пораженного участка обнаружено утолщение эпидермиса с умеренным гипер- и паракератозом, слабовыраженный акантоз и спонгиоз, в сосочковом слое густой пролиферат из лимфоцитов различной степени зрелости с наличием малых лимфоцитов с примесью эозинофилов, ядра клеток различной формы 

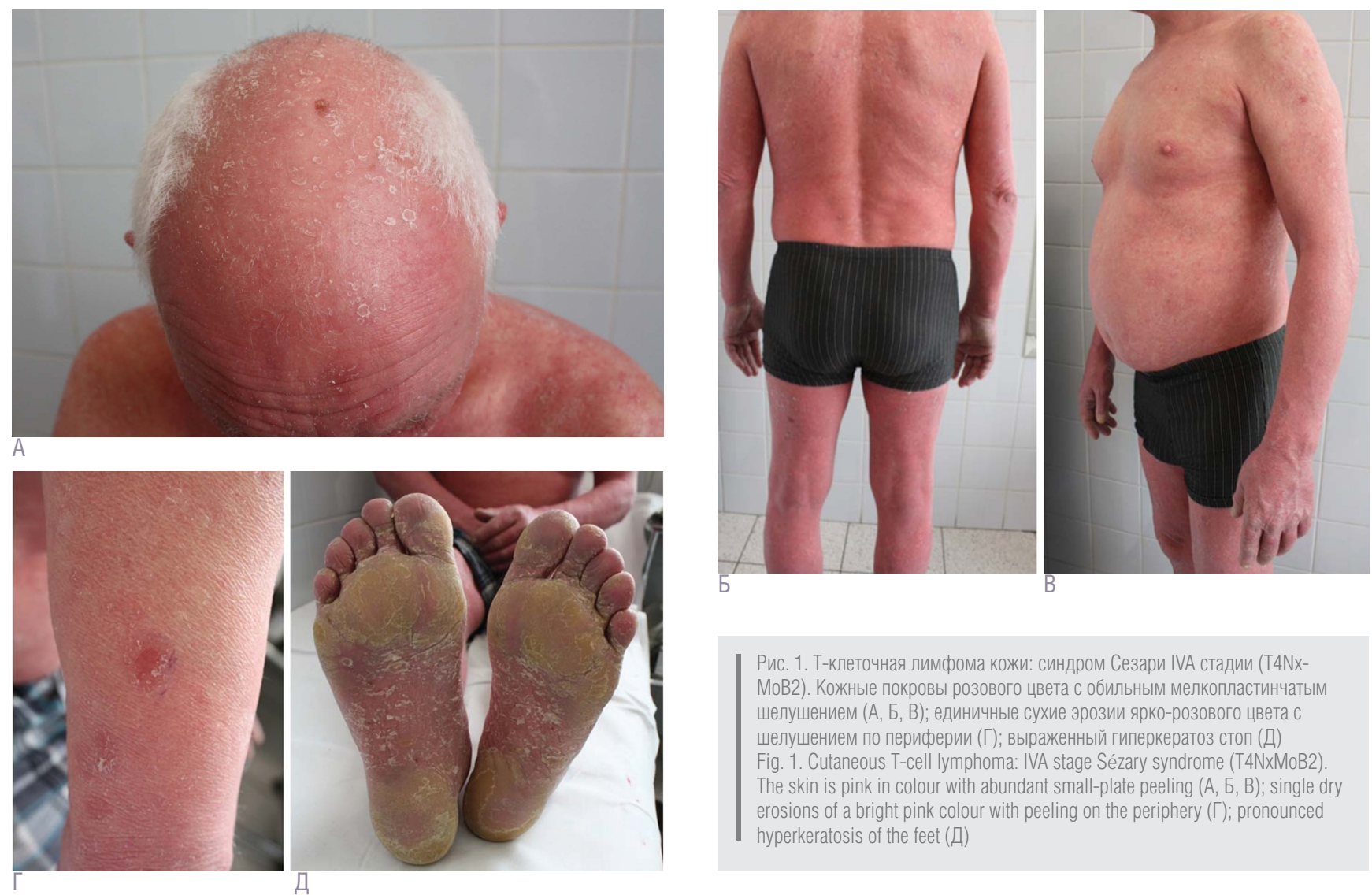

Б

B

Рис. 1. Т-клеточная лимсома кожи: синдром Сезари IVA стадии (T4NxМоВ2). Кожные покровы розового цвета с обильным мелкопластинчатым шелушением (А, Б, В); единичные сухие эрозии ярко-розового цвета с шелушением по периферии (Г); выраженный гиперкератоз стоп (Д) Fig. 1. Cutaneous T-cell lymphoma: IVA stage Sézary syndrome (T4NxMoB2). The skin is pink in colour with abundant small-plate peeling $(A, B, B)$; single dry erosions of a bright pink colour with peeling on the periphery $(\Gamma)$; pronounced hyperkeratosis of the feet (Д)
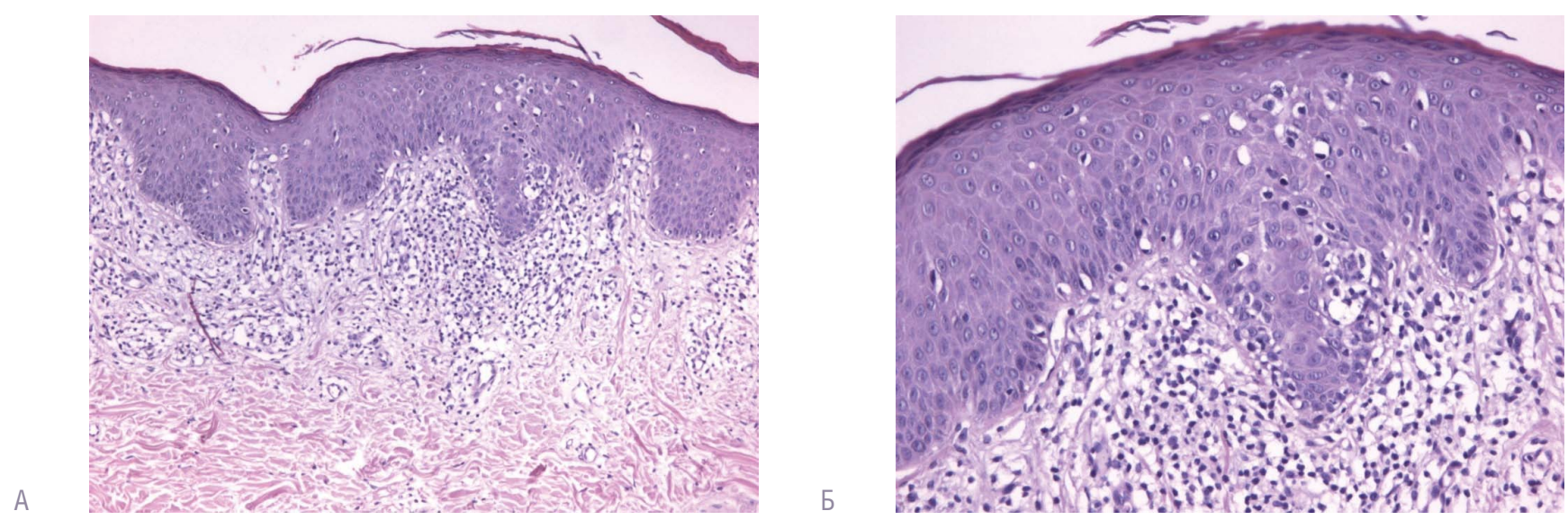

\begin{abstract}
Рис. 2. Морфологическое исследование биоптата кожи больного синдромом Сезари. Утолщение эпидермиса с умеренным гипер- и паракератозом, слабовыраженным акантозом и спонгиозом. В сосочковом слое густой пролисеерат из лимфоцитов различной степени зрелости с наличием малых лимфоцитов с примесью эозинофилов, ядра клеток различной формы и размеров. Выраженный эпидермотропизм на отдельных участках с тенденцией к формированию микроабсцессов. Окраска гематоксилином и эозином, x100 (А); ×200 (Б)

Fig. 2. Morphological examination of a skin biopsy sample from a Sézary syndrome patient. Thickening of the epidermis with moderate hyper- and parakeratosis, mild acanthosis and spongiosis. The papillary layer features a thick proliferate consisting of the lymphocytes of various degrees of maturity with the presence of small lymphocytes mixed with eosinophils, the cell nucleus of various shapes and sizes. Pronounced epidermotropism in individual areas with a tendency to form microabscesses. Staining with hematoxylin

and eosin. $\times 100(\mathrm{~A}) ; \times 200(\mathrm{~B})$
\end{abstract}

и размеров. Отмечался выраженный эпидермотропизм на отдельных участках с тенденцией к формированию микроабсцессов (рис. 2). Выявленные морфологические изменения не позволяли исключить диагноз лимфомы кожи, на основании чего пациенту был выставлен диагноз: «Эритродермическая форма грибовидного микоза T4NxMx. Синдром Сезари?» Отсутствие у больного в анамнезе указаний на проявления пятнистой и бляшечной стадии грибовидного микоза, эритродермический характер высыпаний, генерализованная лим- фораденопатия, ладонно-подошвенный гиперкератоз, алопеция стали основанием для продолжения обследования с целью подтверждения диагноза - синдрома Сезари.

Пациент консультирован в Гематологическом научном центре Минздрава России, где выполнен пересмотр гистологических препаратов кожи, результаты которого: «В готовом препарате и препарате, изготовленном из блока, фрагменты кожи с гиперпаракератозом, неравномерным акантозом. В верхних отделах 
дермы - участки фриброза сосочкового слоя с полосовидной лимфоидной инфильтрацией преимущественно из среднего размера клеток с церебриформными ядрами, наличием крупных клеток с примесью гистиоцитов, нерезко выраженными признаками эпидермотропизма». Проведено иммуногистохимическое исследование (ИГХ) на срезах с парафинового блока с использованием антител к CD3, CD4, CD5, CD7, CD8, CD20, CD30, $\mathrm{TCR}(\mathrm{bF} 1)$, Ki67: «Выявлена резко преобладающая Т-клеточная инфильтрация $\mathrm{bF}^{+}, \mathrm{CD}^{+}, \mathrm{CD}^{+}, \mathrm{CD} 5^{+}$. Отмечалось резкое снижение эпидермальной/дермальной экспрессии CD7 клетками лимфроидного инфильтрата, присутствие в умеренном количестве рассеянных цитотоксических лимфоцитов $\mathrm{CD}^{+}$. Отдельные лимфоидные клетки небольших размеров, гистиоциты и отдельные плазмоциты экспрессировали активационный антиген CD30+. Мелкие В-клетки $\mathrm{CD}_{20}^{+}$расположены разрозненно среди Т-клеточного лимфоидного пролиферата, были крайне малочисленными. Индекс пролиферативной активности Кі67 - низкий, составляет 5-10 \% позитивных клеток лимфоидного пролиферата». Методом фррагментного анализа в коже и костном мозге пациента выявлена моноклональность по гаммацепи Т-клеточного рецептора. При морфологическом исследовании костного мозга данных за лимфоидное поражение не выявлено. В гемограмме от 25.04.2016 гемоглобин - 149 г/л, тромбоциты - 234 тыс./мкл, лейкоциты - 16,2 тыс/мкл, эозинофилы - $2 \%$, сегментоядерные - $34 \%$, лимфоциты - $47 \%$, моноциты - $5 \%$, клетки Сезари - 22 \%, СОЭ - 1 мм/ч. При выполнении компьютерной томографии органов грудной клетки и ультразвукового исследования органов брюшной полости данных за вовлечение висцеральных лимфатических узлов и внутренних органов не получено. На основании проведенного обследования верифицирован диагноз: «Т-клеточная лимфрома кожи: синдром Сезари IVA стадии (T4NxMoB2)».

\section{Клинический случай 2}

Пациентка Ч., 40 лет обратилась в ФГБУ «ГНЦДК» Минздрава России с жалобами на высыпания на коже головы, лица, туловища, верхних и нижних конечностей, выпадение волос. Со слов пациентки, зуд не беспокоил.

Первые высыпания появились на коже груди в 2008 году, высыпания представляли собой пятна розового цвета без шелушения, сопровождающиеся умеренным зудом. При обращении в КВД по месту жительства установлен диагноз “Контактный дерматит» и назначено лечение топическими глюкокортикостероидами с временным положительным эффректом. В течение двух лет аналогичные высыпания распространились на кожу лица, туловища, верхних и нижних конечностей, самостоятельно использовала топические глюкокортикостероиды без выраженного положительного эффекта. В 2014 году в КВД по месту жительства проведена диагностическая биопсия кожи с очага поражения, морфологическая картина соответствовала диагнозу «Псориаз». На основании клинико-морфологических данных пациентке установлен диагноз «Псориатическая эритродермия» и проведена терапия системными и топическими глюкокортикостероидами, а также дезинтоксикационными и десенсибилизирующими и наружными смягчающими и увлажняющими средствами. С 2014 по 2017 год неоднократно находилась на стационар- ном лечении в КВД по месту жительства, где получала аналогичную терапию. В мае 2018 года в связи с ухудшением со стороны кожного патологического процесса и отсутствием эфрфекта от проводимого лечения впервые обратилась в ФГБУ «ГНЦДК» Минздрава России для уточнения диагноза и лечения.

При поступлении кожный процесс носил распространенный характер. Высыпания локализовались на коже волосистой части головы, лица, туловища, верхних и нижних конечностей. На коже волосистой части головы - бледно-розовые пятнистые высыпания с мелкопластинчатым шелушением, при осмотре обращало на себя внимание диффузное проредение волос и наличие единичных эрозий ярко-розового цвета с влажной поверхностью. На коже лба, щек и периоральной области наблюдались высыпания ярко-розового цвета без шелушения, местами с умеренной инфильтрацией. На коже туловища, верхних и нижних конечностей - множественные, сливающиеся между собой пятнистые элементы без четких границ с умеренным мелкопластинчатым шелушением, интенсивность окраски варьировала от розового до ярко-розового цвета, местами с буроватым оттенком, на коже спины отмечались немногочисленные мелкие эрозии розового цвета с влажной поверхностью. На коже груди, живота, верхней трети спины и передней поверхности бедер отмечались участки видимо здоровой кожи. На коже ладонных поверхностей кистей и подошвенных поверхностей стоп - умеренный гиперкератоз (рис. 3). При пальпации увеличения периферических лимфатических узлов выявлено не было.

Учитывая полиморфизм высыпаний, наличие диффузного поредения волос и умеренного гиперкератоза ладоней и подошв, проявления заболевания были крайне подозрительны в отношении лимфопролиферативного заболевания кожи.

При морфологическом исследовании биоптата кожи с пораженного участка обнаружен густой полосовидный инфильтрат в сосочковой дерме, состоящий из полиморфных лимсоцитов с укрупненными ядрами неправильной фрормы, а также с примесью малых лимфоцитов с гиперхромными ядрами; с тенденцией клеток пролиферата к экзоцитозу в эпидермис с формированием множественных внутриэпидермальных микроабсцессов по типу Потрие. Выявленная патогистологическая картина наиболее соответствовала Т-клеточной лимфоме коже (рис. 4).

Для верификации диагноза на срезах с парафинового блока проведено ИГХ-исследование с использованием антител к CD3, CD4, CD8, CD20, CD30, Granzyme B, Ki-67. Клетки лимфоидного пролиферата, в том числе расположенные интраэпидермально, экспрессировали CD3 (мембранная реакция), CD4 (мембранная реакция), Индекс пролиферативной активности Кі-67 составляет на разных участках от 10 до $15 \%$. Присутствовала скудная примесь цитотоксической Т-клеточной популяции (CD8 ${ }^{+}$, Granzyme B+), В-клеток (CD20+), гистиоцитов и плазмоцитов клеток $\left(\mathrm{CD} 30^{+}\right)$. Морфологическая картина и иммунофенотип характеризовали субстрат грибовидного микоза.

Пациентке установлен диагноз грибовидного микоза, стадия IB и проведен курс фрототерапии и наружной терапии, выписана с рекомендациями повторной госпитализации в ФГБУ «ГНЦДК» Минздрава России 

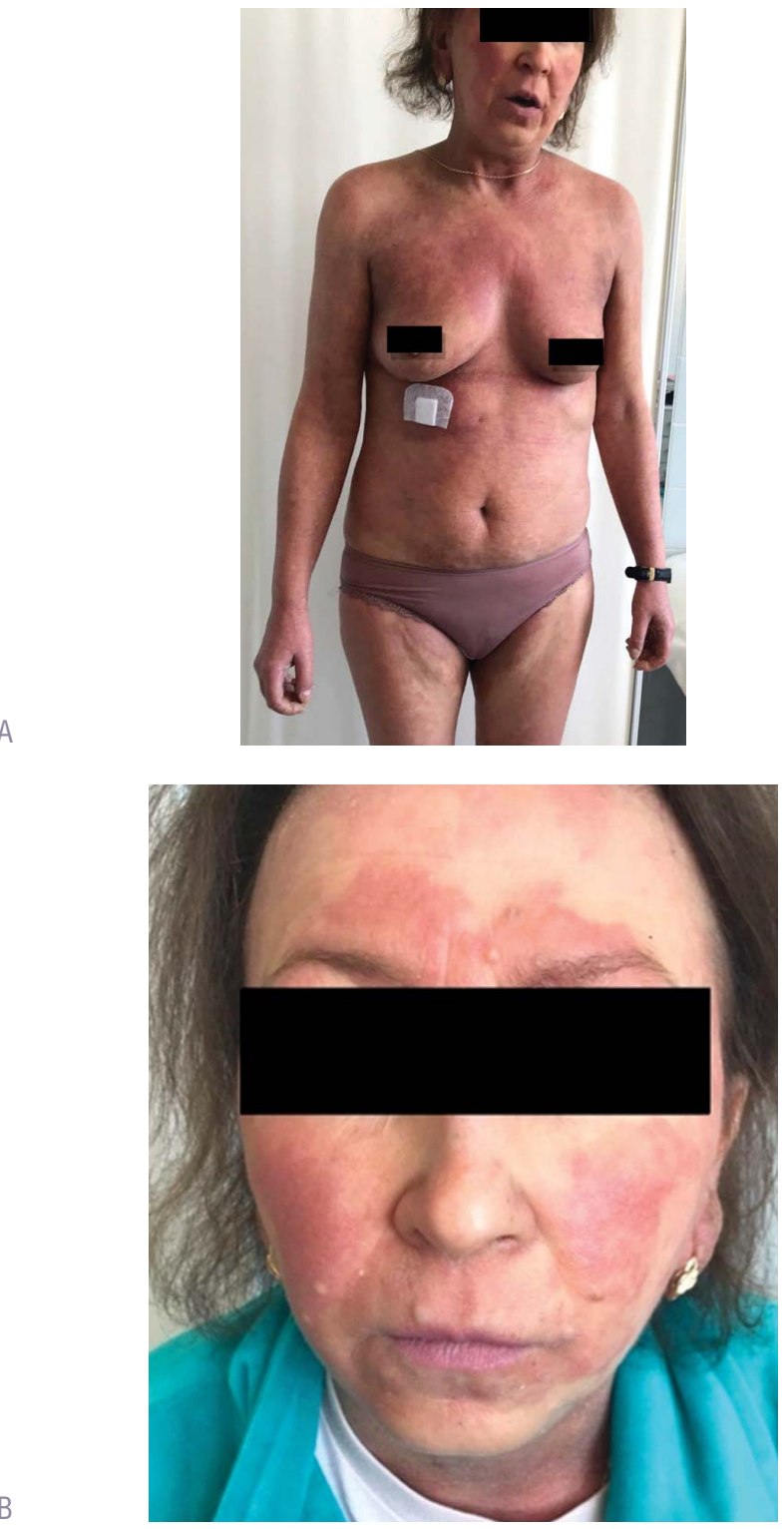

Б
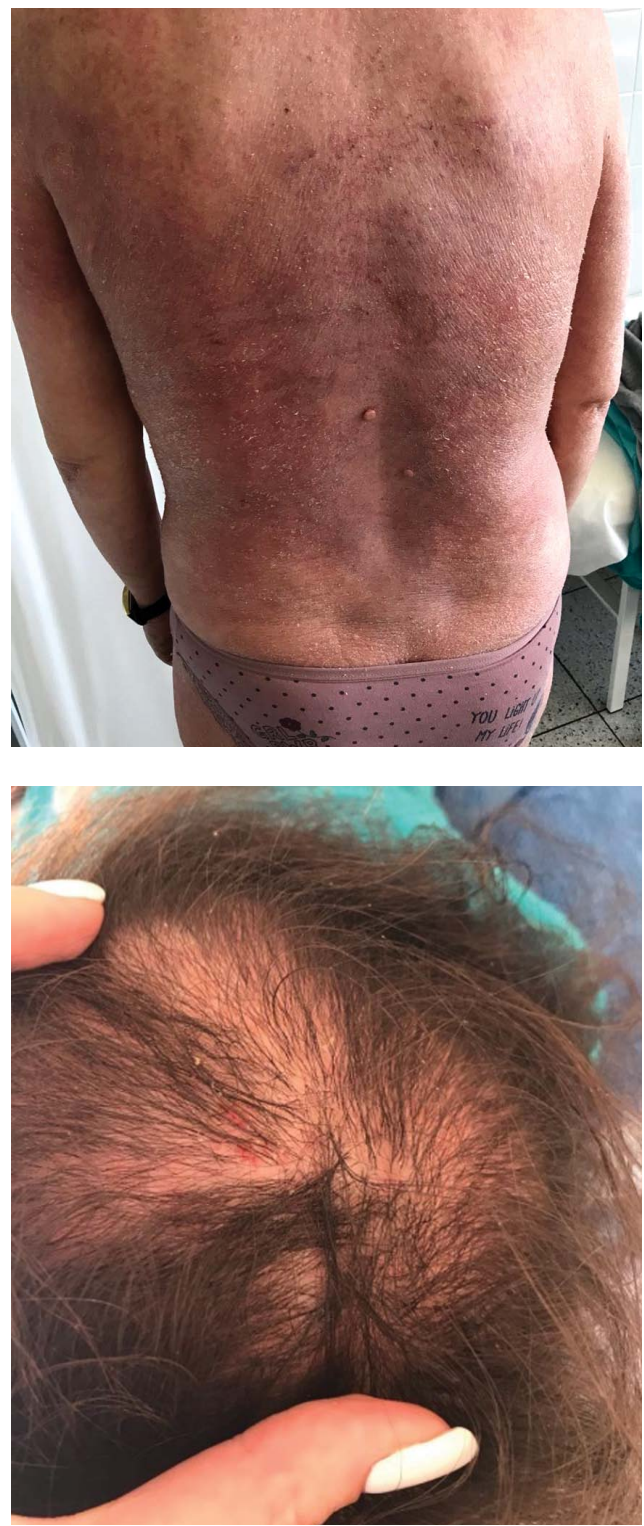

Рис. 3. Т-клеточная лимфома кожи: Грибовидный микоз, стадия IB (Т2NхMoBx). Множественные пятнистые высыпания с мелкопластинчатым шелушением (А, Б); высыпания на коже лица по типу красной волчанки (В); единичные эрозии ярко-розового цвета (Г)

Fig. 3. Cutaneous T-cell lymphoma: Mycosis fungoides, stage IB (T2NxMoBx). Multiple spotted rashes with fine-plate peeling (A, Б); rashes on the face similar to those in lupus erythematosus (B); single erosions of a bright pink colour ( $\Gamma$ )

через 1 месяц. В сентябре 2018 года в связи с ухудшением со стороны кожного патологического процесса находилась на лечении в онкологическом диспансере, где получала внутривенные инфузии метотрексата (доза и количество инфрузий в выписке не указаны) и терапию системными глюкокортикостероидами с временным положительным эфффектом. В октябре 2018 года в связи с выраженным ухудшением состояния повторно обратилась в ФГБУ «ГНЦДК» Минздрава России.

При поступлении патологический процесс носил характер эритродермии, диффузная эритема розового и ярко-розового цвета занимала более $90 \%$ площади поверхности тела. Усилились проявления гиперкератоза ладоней и подошв, а также диффузного поредения волос, которое стало затрагивать область бровей и ресниц. Обращала на себя внимание выраженная инфильтрация мочек ушей (рис. 5). При пальпации выявлено увеличение подчелюстных, шейных, подмы- шечных и паховых лимфатических узлов, в связи с чем пациентке проведено УЗИ периферических лимфратических узлов, обнаружены эхографические признаки изменения периферических лимфатических узлов по типу лимфопролиферативного процесса.

Усиление клинической симптоматики (эритродермия, выраженный гиперкератоз ладоней и подошв, диффузное поредение волос) и обнаружение увеличенных лимфатических узлов требовало проведения дифференциальной диагностики между Э-ГМ и СС. Пациентке проведено иммунофенотипирование лимфоцитов периферической крови. Среди популяции Т-лимфоцитов 62,3 \% клеток носили аберрантный иммунофенотип с отсутствием экспрессии CD7 и CD26, выявлена моноклональность по Vb3-цепи T-клеточного рецептора. Иммунофренотип соответствовал диагнозу синдрома Сезари.

На основании проведенного обследования пациентке установлен диагноз: «Т-клеточная лимфома 

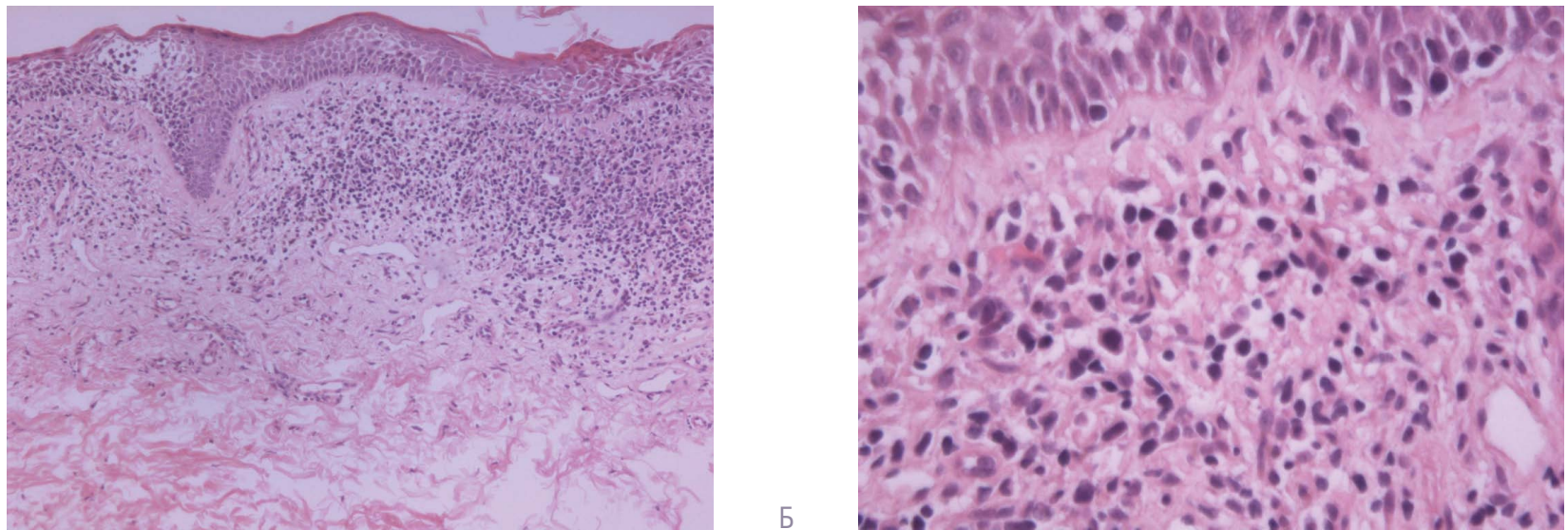

\begin{abstract}
Рис. 4. Морфологическое исследование кожи больного синдромом Сезари. Окраска гематоксилином и эозином, х100. Эпидермис уплощен. В сосочковой дерме — густой пролиферат из лимффоцитов с тенденцией к их экзоцитозу и формиированию микроабсцессов Потрие (А). Окраска гематоксилином и эозином, х400. В составе клеток инфильтрата — полиморфные лимфоциты с резко укрупненными ядрами неправильной формы. Ядра лимсооцитов, проникающих в эпидермис, также укрупнены (Б) Fig. 4. Morphological examination of a skin biopsy sample from a Sézary syndrome patient. Staining with hematoxylin and eosin, $\times 100$. The epidermis is flattened. The papillary dermis features a thick proliferate of lymphocytes with a tendency to exocytosis and the formation of Pautrier's microabscesses (A). Staining with hematoxylin and eosin, $\times 400$. The composi-

tion of infiltrate cells features polymorphic lymphocytes with sharply enlarged nuclei of irregular shape. The lymphocyte nuclei penetrating the epidermis are also enlarged (Б)
\end{abstract}
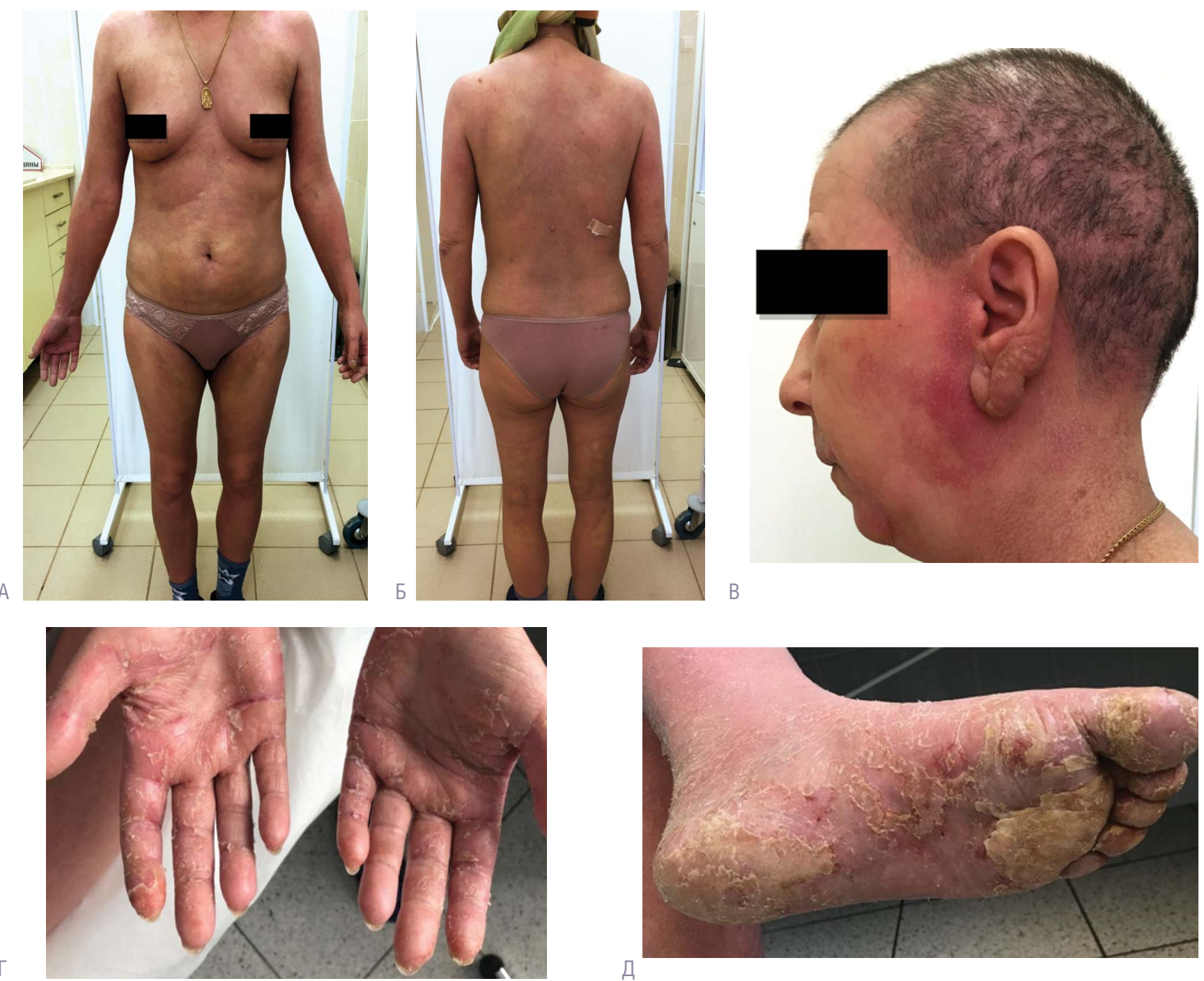

Д
Рис. 5. Т-клеточная лимфома кожи: синдром Сезари IVA стадии (T4NxMoB2). Эритродермия (А, Б); инфильтрация мочек ушей (B); выраженный гиперкератоз ладоней и подошв (Г, Д)
Fig. 5. Cutaneous T-cell lymphoma: IVA stage Sézary syndrome (T4NxMoB2). Erythroderma (A, E); infiltration of the earlobes (B); pronounced hyperkeratosis of the palms and soles (Г, Д)


кожи: синдром Сезари IVA стадии (T4NxMoB2)». Учитывая диагноз, пациентке было рекомендовано обратиться для дальнейшего обследования и лечения к врачу-гематологу.

\section{Обсуждение}

Как было показано на примере двух пациентов, в диффференциальной диагностике эритродермических состояний при Т-клеточных лимфомах кожи ведущая роль отводится проведению исследований периферической крови, направленных на подсчет клеток Сезари и/или определение иммунофенотипа циркулирующих Т-лимфоцитов.

Следует отметить, что результаты морфологического и ПЦР-исследования не дают однозначного ответа при дифференциальной диагностике между Э-ГМ и СС. Морфологические признаки при СС схожи с таковыми при грибовидном микозе, однако при СС они обладают меньшей выраженностью проявлений: отмечается более тонкий лимфоцитарный инфильтрат со слабым и зачастую отсутствующим эпидермотропизмом. Согласно данным Klemke CD и соавт. (2015 г.), около трети результатов гистологических исследований при СС не обладают специфическими проявлениями и характеризуют субстрат хронических дерматозов $[12,19]$.
При проведении ПЦР-анализа для определения клональности Т-лимфоцитов по реаранжировке гена Т-клеточного рецептора важно помнить, что обнаружение моноклональности клеток инфильтрата может наблюдаться при доброкачественных дерматозах и не является определяющим признаком для злокачественного лимфопролифреративного процесса, что требует корреляции с клиническими проявлениями и результатами других исследований [20].

Несмотря на схожесть клинических, а зачастую и морфологических проявлений при Э-ГМ и СС, это два разных заболевания, берущих начало из разных субпопуляций Т-клеток памяти, что влияет не только на прогноз заболевания, но и на тактику его лечения $[11,12]$.

Приведенные клинические случаи представляют интерес не только для врачей-дерматовенерологов, но и для гематологов и онкологов. Успешный опыт взаимодействия дерматологов, патоморфологов и гематологов позволил провести адекватное обследование и установить пациентам заключительный диагноз синдрома Сезари, что подчеркивает важность междисциплинарного взаимодействия в диагностики и дальнейшей маршрутизации больных с Т-клеточными лимфомами кожи.

\section{Литература/References}

1. Burns T. et al. Rook's textbook of dermatology. 8th ed. Oxford: Willey-Blackwell, 2010. Vol. 4. P. 4432.

2. Wolf $K$. et al. Fitzpatrick's dermatology in general medicine. 7th ed. New York: McGraw-Hill, 2007. P. 225-232.

3. Sigurdsson V., Steegmans P. H., van Vloten W. A. The incidence of erythroderma: a survey among all dermatologists in The Netherlands. J Am Acad Dermatol. 2001;45(5):675-678.

4. Rothe M. J., Bernstein M. L., Grand-Kels J. M. Life-threatening erythroderma: diagnosing and treating "the red" man. Clin Dermatol. 2005;23:206-217.

5. Sarkar R., Sharma R. C., Koranne R. V. et al. Erythroderma in children — a clinico-etiologic study. J Dermatol. 1999;26:507-511.

6. Каламкарян А. А., Авербах Е. В., Забанова Е. В., Персина И. С. Клинические особенности злокачественных лимфом кожи. Вестник дерматологии и венерологии. 1989;(12):8-12. [Kalamkaryan A. A., Averbakh E. V., Zabanova E. V., Persina I. S. Clinical features of malignant skin lymphomas. Vestnik Dermatologii i Venerologii. 1989;(12):8-12. (In Russ.)]

7. Родионов А. Н. Эритодермическая лимфома кожи: Учебное пособие. Л., 1989. 67 с. [Rodionov А. N. Erythrodermic skin lymphoma: Textbook. Leningrad, 1989. 67 p. (In Russ.)]

8. Сейкетова О. Ж., Джумамуратова Д. И. Результаты клинического обследования больных псориазом за 10 лет. Вестник дерматологии и венерологии. 1970;(1):19-21. [Seyketova 0. Zh., Dzhumamuratova $\mathrm{D}$. I. Results of a 10-year clinical monitoring of psoriasis patients. Vestnik Dermatologii i Venerologii. 1970;(1):19-21. (In Russ.)]

9. Pileri A., Pellegrini C., Agostinelli C. et al. Erythroderma and non-Hodgkin T-cell lymphoma: what else, apart from mycosis fungoides and Sézary syndrome? Eur J Dermatol. 2017;27(1):49-53.

10. Gros A., Laharanne E., Vergier M. et al. TP53 alterations in primary and secondary Sézary syndrome: A diagnostic tool for the as- sessment of malignancy in patients with erythroderma. PLoS One. 2017:12(3):e0173171.

11. Martinez X. U., Di Raimondo C., Abdulla F. R., Zain J., Rosen S. T., Querfeld $C$. et al. Leukaemic variants of cutaneous T-cell lymphoma: Erythrodermic mycosis fungoides and Sézary syndrome. Best Pract Res Clin Haematol. 2019 Sep;32(3):239-252.

12. Willemze R., Cerroni L., Kempf W., Berti E., Facchetti F., Swerdlow S. H. et al. The 2018 update of the WHO-EORTC classification for primary cutaneous lymphomas. Blood. 2019 Jan;133(16):1703-1714.

13. Vonderheid E. C., Bernengo M. G., Burg G., Duvic M., Heald P., Laroche $\mathrm{L}$. et al. Update on erythrodermic cutaneous T-cell lymphoma: report of the international society for cutaneous lymphomas. J Am Acad Dermatol. 2002 Jan;46(1):95-106.

14. Olsen E., Vonderheid E., Pimpinelli N., Willemze R., Kim Y., Knobler R. et al. Revisions to the staging and classification of mycosis fungoides and sezary syndrome: a proposal of the international society for cutaneous lymphomas (ISCL) and the cutaneous lymphoma task force of the European organization of Research and treatment of cancer (EORTC). Blood. 2007 Sep 15;110(6):1713-1722.

15. Olsen E.A., Rook A.H., Zic J., Kim Y., Porcu P., Querfeld C. et al. Sezary syndrome: immunopathogenesis, literature review of therapeutic options, and recommendations for therapy by the United States Cutaneous Lymphoma Consortium (USCLC). J Am Acad Dermatol. 2011 Feb;64(2):352-404

16. Белоусова И. Э., Казаков Д. В., Криволапов Ю. А. Современные подходы к диагностике и лечению первичных лимфом кожи на основе новой B03/ EORTC - классификации. Т-клеточные лимфомы кожи. Архив патологии. 2007;69(5):11-17. [Belousova I. Е., Kazakov D. V., Krivolapov Yu. A. Modern approaches to the diagnostics and treatment of primary skin lymphomas based on a new WHO/ 
EORTC classification. Cutaneous T-cell Iymphomas. Arkhiv Pathologii. 2007;69(5):11-17. (In Russ.)]

17. Burg G., Kempf W. Cutaneous Lymphomas (Basic and Clinical Dermatology). Informa Health-care, 2005. 592 p.

18. Mistry N., Gupta A., Alavi A., Sibbald R. G. A review of the diagnosis and management of erythroderma (generalized red skin). Adv Skin Wound Care. 2015;28(5):228-236.
19. Klemke C. D., Booken N., Weiss C. et al. Histopathological and immunophenotypicalcriteria for the diagnosis of Sézary syndrome indifferentiation from other erythrodermic skindiseases: a European Organisation for Re-search and Treatment of Cancer (EORTC)Cutaneous Lymphoma Task Force Study of97 cases. Br J Dermatol. 2015;173(1):93-105.

20. Olsen E. A. Evaluation, diagnosis, and staging of cutaneous lymphoma. Dermatol Clin. 2015 0ct;33(4):643-654.

\section{Информация об авторах}

Арфеня Эдуардовна Карамова - к.м.н., заведующая отделом дерматологии Государственного научного центра дерматовенерологии и косметологии Министерства здравоохранения Российской Федерации

Вадим Викторович Чикин - Д.м.н., старший научный сотрудник отдела дерматологии Государственного научного центра дерматовенерологии и косметологии Министерства здравоохранения Российской Федерации

Людмила Федоровна Знаменская - д.м.н., ведущий научный сотрудник отдела дерматологии Государственного научного центра дерматовенерологии и косметологии Министерства здравоохранения Российской Федерации

Анастасия Александровна Воронцова* - младший научный сотрудник отдела дерматологии Государственного научного центра дерматовенерологии и косметологии Министерства здравоохранения Российской Федерации; e-mail: vorontsova@cnikvi.ru

\section{Information about the authors}

Arfenya E. Karamova - Cand. Sci. (Med.), Head of the Department of Dermatology, State Research Center of Dermatovenereology and Cosmetology, Ministry of Health of the Russian Federation

Vadim V. Chikin - Dr. Sci. (Med.), Senior Researcher, Department of Dermatology, State Research Center of Dermatovenereology and Cosmetology, Ministry of Health of the Russian Federation

Lyudmila F. Znamenskaya - Dr. Sci. (Med.), Leading Researcher, Department of Dermatology, State Research Center of Dermatovenereology and Cosmetology, Ministry of Health of the Russian Federation

Anastasia A. Vorontsova* - Junior Researcher, Department of Dermatology, State Research Center of Dermatovenereology and Cosmetology, Ministry of Health of the Russian Federation; e-mail: vorontsova@cnikvi.ru 